\title{
The role of poly(ADP-ribose) polymerase inhibitors in the treatment of endometrial cancer: a scoping review of the current literature
}

\author{
Samantha Ricci ${ }^{1}$, Laura Parisi ${ }^{1}$, Amy Knehans $^{2}$, Rebecca Phaeton ${ }^{3}$ and Joshua P Kesterson ${ }^{3 *}$ \\ ${ }^{1}$ Penn State College of Medicine, Hershey, PA, USA \\ ${ }^{2}$ Harrell Health Sciences Library, Penn State College of Medicine, Hershey, PA, USA \\ ${ }^{3}$ Division of Gynecologic Oncology, Penn State Hershey Medical Center, Hershey, PA, USA
}

\begin{abstract}
Objective: To describe, synthesize, and interpret literature on the role of poly (ADP-ribose) polyermase inhibitors in the treatment of endometrial cancer and to identify areas of interest for future reasearch.

Design: Scoping review of the literature covering several study designs.

Setting: Literature review.

Methods: Systematic Searches of the electronic databases PubMed ${ }^{\circledR}\left(\right.$ MEDLINE $\left.^{\circledR}\right)$, Cochrane Library ${ }^{\circledR}$, CINAHL ${ }^{\circledR}$, and Web of Science ${ }^{\mathrm{TM}}$ were performed, as well as web-based searches (ClinicalTrials.gov, Canadian Clinical Trials \& Cancer Trials, Australian Clinical Trials, WHO ICTRP, NIH Reporter, the CDC, and Google Scholar) for additional material, such as reports commissioned by government as well as non-governmental agencies. Literature was identified and organized into categories then synthesized to form conclusions and identify knowledge gaps.

Results: 96 records were identified after searching the literature and 69 records were subsequently reviewed.

Conclusion: There is conflicting evidence regarding the utility of proposed biomarkers in predicting sensitivity of endometrial cancer to PARP inhibitor treatment. Current in vitro and in vivo studies suggest that PARP inhibitors may be effective in the treatment of certain subsets of endometrial cancer, but further research is warranted.
\end{abstract}

\section{Introduction}

Endometrial cancer is the most common gynecologic cancer in the United States [1]. While early-stage cancer is generally cured with surgery, the therapeutic options for advanced and recurrent endometrial cancer are limited, with minimal efficacy, short-lived responses and significant toxicity [2-4]. In fact, the most effective regimens result in an overall survival of 12-15 months [5,6]. These results highlight the need for novel agents, including a shift toward targeting specific molecular and genetic pathways involved in endometrial carcinogenesis. One such target is Poly (ADP-ribose) polymerase, or PARP.

PARP is a family of 17 enzymes that catalyze the polyADPribosylation of proteins involved in the repair of single stranded DNA breaks via the base excision repair (BER) pathway [7,8]. PARP1 is activated in response to metabolic, chemical, or radiation-induced breaks in the DNA strand. Once a single stranded break is detected, PARP1 recruits and activates enzymes needed to repair the damaged strand via the transfer of ADP-ribose molecules from NAD+ to itself and other DNA repair proteins [7,9]. In addition to its role in the repair of single strand break (SSB) DNA, PARP aids in the prevention of formation of double strand breaks (DSB) in DNA via its recognition of stalled replication forks and recruitment of MRE11, which initiates the homologous recombination (HR) pathway [10].
Poly(ADP-ribose) polymerase inhibitors (PARP inhibitors) inhibit PARP function by two major mechanisms. First, they compete with $\mathrm{NAD}+$ for access to the substrate binding site [11] and secondly, they trap PARP1 and PARP2 while complexed with DNA leading to cell death due to blocked DNA repair ability [12]. PARP inhibitors therefore lead to persistence of single stranded breaks in DNA due to impaired BER [9]. If unrepaired, these single stranded breaks lead to replication fork collapse or the generation of double-stranded breaks in DNA. Cells with intact homologous recombination (HR) DNA repair mechanisms are able to repair the double stranded breaks and the cells remain viable. However, in the absence of intact HR, cells are unable to repair double-stranded breaks and subsequently undergo apoptosis [13-15]. This exemplifies the concept of synthetic lethality, in which two specific defects, neither of which are overtly detrimental to the cell individually, but lethal when they occur together.

The synthetic lethality of PARP inhibitor treatment in tumor cells

Correspondence to: Joshua P. Kesterson, Division of Gynecologic Oncology, Department of Obstetrics and Gynecology, Penn State Hershey Medical Center, 500 University Drive, Hershey, PA 17036, Tel: (717) 531-8144 (ext. 5); Fax: (717) 531-0007; E-mail: jkesterson@hmc.psu.edu

Received: April 28, 2016; Accepted: May 30, 2016; Published: June 03, 2016 
with defects in HR repair, including BRCA-mutated ovarian cancers has been demonstrated [16-19]. Clinical trials of monotherapy with the oral PARP inhibitor olaparib have shown objective antitumor activity in ovarian cancer [17-19]. Additional studies have focused on the efficacy of other PARP inhibitors in BRCA mutation carriers [20] and BRCA-mutated cancer cells [21].

Similarly, PARP inhibitors may have increased efficacy in tumors which exhibit "BRCAness"; that is, tumor cells deficient in HR but without a known or detectable BRCA1 or BRCA2 mutation [22]. Mutations in phosphatase and tensin homolog (PTEN) and MRE11 may cause tumor cells to exhibit a "BRCAness" phenotype, due to their role in DNA repair. PTEN is a tumor suppressor gene located on chromosome 10q23.3 that functions as an antagonist of the prosurvival/proliferative PI3K/AKT pathway [23]. In addition to its role in regulating the cell cycle, PTEN is also involved in DNA double-stranded break repair via upregulation of the gene encoding RAD51, a protein involved in DNA repair [23]. A diverse group of mutations in PTEN can lead to the generation of solid tumors; in fact, PTEN mutations are the most common molecular defect in endometrioid endometrial adenocarcinoma [24,25], seen in up to $83 \%$ of these endometrial cancers [24-27]. MRE11 is a protein that, together with RAD51 and NBS1, forms a complex involved in the detection and repair of DSBs in DNA $[28,29]$. The prevalence of MRE11 mutations in endometrial cancer is the subject of investigation, with studies suggesting mutation frequencies ranging from $1.9 \%$ to $50 \%[30,31]$.

Given the frequency of these mutations in endometrial and the implications of impaired DNA repair, it is plausible that endometrial cancers carrying these mutations have inadequate HR and therefore may be sensitive to PARP inhibitors. The purpose of this review is to analyze the current literature regarding the role of PARP inhibitors in the treatment of endometrial cancer, summarize results of available data, and identify areas warranting further research.

\section{Methods}

\section{Eligibility criteria}

A comprehensive literature search was conducted regarding the use of PARP inhibitors in endometrial cancer. Explicit methods aimed at minimizing bias and shadowed the recommended methodologic standards for systematic reviews set out by the Institute of Medicine. Inclusion and exclusion criteria were discussed at the beginning of the scoping process. Studies were considered eligible for inclusion if they 1. examined both endometrial cancer and PARP Inhibitors as therapy and 2. were published in English. There were no restrictions on types of studies to be included. There were no date restrictions.

\section{Identification of literature}

The scoping review was based on a search strategy using the following electronic databases: PubMed ${ }^{\oplus}\left(\right.$ MEDLINE $\left.^{\star}\right)$, Cochrane Library $^{\circ}, \mathrm{CINAHL}^{\circ}$, and Web of Science ${ }^{\mathrm{m}}$, as well as web-based searches (ClinicalTrials.gov, Canadian Clinical Trials \& Cancer Trials, Australian Clinical Trials, WHO ICTRP, NIH Reporter, the CDC, and Google Scholar) for additional material, such as reports commissioned by government as well as non-governmental agencies. The search strategies for medline CINHAL can be found in appendix A.

Permutations of search terms PARP inhibitors and Endometrial Cancer were used to collect a total of 96 bibliographical entries. The electronic search strategies were developed and executed within the databases (October 2014) by experienced information specialists. The bibliographies of included articles were reviewed for additional citations. The search was updated in February 2015 to identify any additional new records.

\section{Review of identified studies}

Prior to the initiation of screening, search results were entered into EndNote 7X Web and duplicate records were removed. Abstracts were reviewed independently by two researchers. All disagreements between reviewers regarding the articles were resolved through discussion. 52 articles were exluded from the review. 31 were excluded because they did not pertain to PARP inhibitors. 14 were excluded because they did not pertain to endometrial cancer. Four were excluded because they looked at PARP cleavage products as markers for apoptosis, no PARP inhibitors. Two were excluded because they did not include discussion of PARP inhibitors for endometrial cancer treatment and one because it did not examine PARP inhibitor efficacy (Table 1). In total, twelve published articles and five clincial trials were identified for inclusion in the review.

\section{Results}

The initial search returned 96 results, of which 17 articles met the study criteria and were subsequently reviewed (Figure 1).

Of the studies selected for analysis, 4 were in vitro [14,32-34], 2 were in vivo [35,36], 6 were reviews $[3,7,37-40]$, and 5 were clinical trials.

\section{In vitro studies}

Dedes et al., using endometrial cancer cell lines, tested whether they were sensitive to PARP inhibition due to the loss of PTEN $[14,34]$. Cells lines which did not express PTEN were more sensitive to treatment with the PARP inhibitor, KU0058948. Furthermore, as proof of its critical role, they silenced PTEN in wild-type PTEN cell lines and noted and increased sensitivity to PARP inhibition. Cell lines lacking PTEN and PARP-inhibitory sensitive, when transduced with wild-type PTEN, had significantly decreased sensitivity to PARP inhibition.

In a more recent paper, investigators from Japan, using endometrial cancer cell lines, evaluated the correlation between PTEN status and olaparib sensitivity [32]. Endometrial cancer cell lines, PTEN-null and wild-type PTEN, were exposed to olaparib at varying concentrations, for 2-3 weeks and the concentration to inhibit cell survival to $50 \%$ (SF50) was calculated. The antiproliferative effects of olaparib varied depending on the cancer cell line, with SF50 ranging from $8 \mathrm{nM}$ to $2500 \mathrm{nM}$. The PTEN status of cell lines was not shown to correlate with sensitivity to olaparib. However, a fourth of PTEN-deficient cells were sensitive to olaparib, with SF50 values $<100 \mathrm{nM}$. RAD51 expression was not correlated with PTEN status. The authors concluded that while PTEN is not a predictive biomarker for olaparib sensitivity, PARP inhibitors may still provide a promising therapeutic strategy in certain endometrial cancers.

Koppensteiner et al. sought to determine if loss of MRE11 would result in increased sensitivity to a PARP-inhibitor [33]. Among endometrial cancers tested, nearly one third lacked MRE11 staining. When endometrial cancer cell lines were tested for PARP-inhibitor sensitivity with BMN673, the cell line lacking MRE11 expression was the most sensitive. When MRE11 was depleted via siRNA, the previously PARP-I resistant cell lines were rendered PARP inhibitor 
Table 1. Excluded citations and reasons for exclusion.

\begin{tabular}{|c|c|c|}
\hline Reason for Exclusion & Title & Authors \\
\hline \multirow[t]{31}{*}{ Not About PARP Inhibitors } & $\begin{array}{l}\text { [Effects of trichostatin A and paclitaxel on apoptosis and mitochondrial membrane potential of } \\
\text { human endometrial carcinoma Ark2 cells] }\end{array}$ & Y. N. Yang, Y. Wang, X. G. Wang and S. J. Jiang \\
\hline & $\begin{array}{l}\text { Icaritin Causes Sustained ERK1/2 Activation and Induces Apoptosis in Human Endometrial } \\
\text { Cancer Cells }\end{array}$ & $\begin{array}{l}\text { J. S. Tong, Q. H. Zhang, X. Huang, X. Q. Fu, S. T. Qi, Y. P. } \\
\text { Wang, Y. Hou, J. Sheng and Q. Y. Sun }\end{array}$ \\
\hline & $\begin{array}{l}\text { Aberrantly activated pSTAT3-Ser727 in human endometrial cancer is suppressed by HO-3867, } \\
\text { a novel STAT3 inhibitor }\end{array}$ & $\begin{array}{l}\text { B. J. Tierney, G. A. McCann, S. Naidu, K. S. Rath, U. Saini, } \\
\text { R. Wanner, P. Kuppusamy, A. Suarez, P. J. Goodfellow, D. } \\
\text { E. Cohn and K. Selvendiran }\end{array}$ \\
\hline & $\begin{array}{l}\text { Synuclein-gamma (SNCG) may be a novel prognostic biomarker in uterine papillary serous } \\
\text { carcinoma }\end{array}$ & $\begin{array}{l}\text { J. Morgan, A. V. Hoekstra, E. Chapman-Davis, J. L. Hardt, } \\
\text { J. J. Kim and B. M. Buttin }\end{array}$ \\
\hline & $\begin{array}{c}\text { [Effects of trichostatin A and paclitaxel on apoptosis and microtubule stabilization in } \\
\text { endometrial carcinoma cells: an in vitro research] }\end{array}$ & S. J. Jiang, S. Zhang, X. Y. Mu, W. Li and Y. Wang \\
\hline & $\begin{array}{l}\text { Histone deacetylase inhibitors induce apoptosis in both Type I and Type II endometrial cancer } \\
\text { cells }\end{array}$ & $\begin{array}{l}\text { S. J. Jiang, S. C. Dowdy, X. W. Meng, Z. Y. Wang, M. B. } \\
\text { Jones, K. C. Podratz and S. W. Jiang }\end{array}$ \\
\hline & $\begin{array}{l}\text { Polymorphisms in base excision repair genes are associated with endometrial cancer risk } \\
\text { among postmenopausal Japanese women }\end{array}$ & $\begin{array}{l}\text { S. Hosono, K. Matsuo, H. Ito, I. Oze, K. Hirose, M. } \\
\text { Watanabe, T. Nakanishi, K. Tajima and H. Tanaka }\end{array}$ \\
\hline & $\begin{array}{l}\text { Description of the cytotoxic effect of a novel drug Abietyl-Isothiocyanate on endometrial } \\
\text { cancer cell lines }\end{array}$ & $\begin{array}{l}\text { T. C. Horan, M. A. Zompa, C. T. Seto, K. K. Kim, R. G. } \\
\text { Moore and T. S. Lange }\end{array}$ \\
\hline & Endometrial cancer cell survival and apoptosis is regulated by protein kinase $\mathrm{C}$ alpha and delta & $\begin{array}{l}\text { J. M. Haughian, T. A. Jackson, D. M. Koterwas and A. P. } \\
\text { Bradford }\end{array}$ \\
\hline & $\begin{array}{l}\text { 17-Allyamino-17-demethoxygeldanamycin and } 17-\mathrm{NN} \text {-dimethyl ethylene diamine- } \\
\text { geldanamycin have cytotoxic activity against multiple gynecologic cancer cell types }\end{array}$ & D. R. Gossett, M. S. Bradley, X. H. Jin and J. Y. Lin \\
\hline & Involvement of Akt isoforms in chemoresistance of endometrial carcinoma cells & $\begin{array}{l}\text { J. Girouard, M. J. Lafleur, S. Parent, V. Leblanc and E. } \\
\text { Asselin }\end{array}$ \\
\hline & $\begin{array}{l}\text { Non-steroidal anti-inflammatory drugs inhibit cellular proliferation and upregulate } \\
\text { cyclooxygenase-2 protein expression in endometrial cancer cells }\end{array}$ & $\begin{array}{l}\text { J. C. Gao, K. Niwa, W. S. Sun, M. Takemura, Z. L. Lian, K. } \\
\text { Onogi, M. Seishima, H. Mori and T. Tamaya }\end{array}$ \\
\hline & $\begin{array}{l}\text { 2,3-Diaryl-2H-1-benzopyran derivatives interfere with classical and non-classical estrogen } \\
\text { receptor signaling pathways, inhibit Akt activation and induce apoptosis in human endometrial } \\
\text { cancer cells }\end{array}$ & $\begin{array}{l}\text { I. Fatima, V. Chandra, R. Saxena, M. Manohar, Y. Sanghani, } \\
\text { K. Hajela, M. P. S. Negi, P. L. Sankhwar, S. K. Jain and A. } \\
\text { Dwivedi }\end{array}$ \\
\hline & $\begin{array}{l}\text { Tubulin inhibitor AEZS } 112 \text { inhibits the growth of experimental human ovarian and } \\
\text { endometrial cancers irrespective of caspase inhibition }\end{array}$ & $\begin{array}{l}\text { J. B. Engel, T. Schonhals, C. Weidler, S. Hausler, M. } \\
\text { Krockenberger, L. Rieger, J. Dietl, J. Wischhusen and A. } \\
\text { Honig }\end{array}$ \\
\hline & $\begin{array}{c}\text { Tumor suppressor effect of follistatin-like } 1 \text { in ovarian and endometrial carcinogenesis-025EFa } \\
\text { differential expression and functional analysis }\end{array}$ & $\begin{array}{l}\text { Q. K. Y. Chan, H. Y. S. Ngan, P. P. C. Ip, V. W. S. Liu, W. C. } \\
\text { Xue and A. N. Y. Cheung }\end{array}$ \\
\hline & $\begin{array}{l}\text { Assessing the efficacy of targeting the phosphatidylinositol 3-kinase/AKT/mTOR signaling } \\
\text { pathway in endometrial cancer }\end{array}$ & $\begin{array}{l}\text { L. S. Bradford, A. Rauh-Hain, R. M. Clark, J. W. } \\
\text { Groeneweg, L. Zhang, D. Borger, L. R. Zukerberg, W. B. } \\
\text { Growdon, R. Foster and B. R. Rueda }\end{array}$ \\
\hline & Induction of apoptosis in endometrial cancer cells by psammaplysene A involves FOXO1 & E. Berry, J. L. Hardt, J. Clardy, J. R. Lurain and J. J. Kim \\
\hline & $\begin{array}{l}\text { Insulin-like growth factor-I receptor (IGF-IR) targeting with monoclonal antibody } \\
\text { cixutumumab (IMC-A12) inhibits IGF-I action in endometrial cancer cells }\end{array}$ & $\begin{array}{l}\text { Z. Attias-Geva, I. Bentov, D. L. Ludwig, A. Fishman, I. } \\
\text { Bruchim and H. Werner }\end{array}$ \\
\hline & $\begin{array}{l}\text { Mechanism of apicidin-induced cell cycle arrest and apoptosis in Ishikawa human endometrial } \\
\text { cancer cells }\end{array}$ & $\begin{array}{l}\text { M. Y. Ahn, J. Lee, Y. J. Na, W. S. Choi, B. M. Lee, K. W. } \\
\text { Kang and H. S. Kim }\end{array}$ \\
\hline & $\begin{array}{l}\text { Molecular mechanism of ursolic acid induced apoptosis in poorly differentiated endometrial } \\
\text { cancer HEC108 }\end{array}$ & Y. Achiwa, K. Hasegawa and Y. Udagawa \\
\hline & $\begin{array}{l}\text { Ursolic acid induces Bax-dependent apoptosis through the caspase-3 pathway in endometrial } \\
\text { cancer SNG-II cells }\end{array}$ & Y. Achiwa, K. Hasegawa, T. Komiya and Y. Udagawa \\
\hline & $\begin{array}{c}\text { Icaritin causes sustained ERK1/2 activation and induces apoptosis in human endometrial } \\
\text { cancer cells. }\end{array}$ & $\begin{array}{l}\text { J. S. Tong, Q. H. Zhang, X. Huang, X. Q. Fu, S. T. Qi, Y. P. } \\
\text { Wang, Y. Hou, J. Sheng and Q. Y. Sun }\end{array}$ \\
\hline & $\begin{array}{l}\text { The synergistic apoptotic interaction of Indole-3-Carbinol and Genistein with TRAIL on } \\
\text { endometrial cancer cells. }\end{array}$ & $\begin{array}{l}\text { B. Parajuli, S. J. Shin, S. H. Kwon, S. D. Cha, H. G. Lee, I. } \\
\text { Bae and C. H. Cho }\end{array}$ \\
\hline & $\begin{array}{l}\text { PARP-1 activity in normal and cancerous human endometrium and its relationship with } \\
\text { quantity of abasic sites (AP) }\end{array}$ & Postawski K1, Monist M, Keith G. \\
\hline & Expression of DNA repair proteins in endometrial cancer predicts disease outcome & $\begin{array}{l}\text { P. Mhawech-Fauceglia, D. Wang, G. Kim, M. Sharifian, X. } \\
\text { W. Chen, Q. Liu, Y. G. Lin, S. Liu and T. Pejovic }\end{array}$ \\
\hline & $\begin{array}{l}\text { Poly(ADP-ribose) polymerase-1, a novel partner of progesterone receptors in endometrial } \\
\text { cancer and its precursors }\end{array}$ & $\begin{array}{l}\text { L. Ghabreau, J. P. Roux, P. O. Frappart, P. Mathevet, L. M. } \\
\text { Patricot, M. Mokni, S. Korbi, Z. Q. Wang, W. M. Tong and } \\
\text { L. Frappart }\end{array}$ \\
\hline & $\begin{array}{l}\text { Poly(ADP-ribose) polymerase (PARP) and DNA-fragmentation factor (DFF45): expression } \\
\text { and correlation in normal, hyperplastic and neoplastic endometrial tissues }\end{array}$ & H. Brustmann \\
\hline & $\begin{array}{l}\text { Hypomethylation of ETS transcription factor binding sites and upregulation of PARP1 } \\
\text { expression in endometrial cancer }\end{array}$ & F. F. Bi, D. Li and Q. Yang \\
\hline & $\begin{array}{c}\text { Consequences of the loss of p53, RB1, and PTEN: Relationship to gefitinib resistance in } \\
\text { endometrial cancer }\end{array}$ & L. Albitar, M. B. Carter, S. Davies and K. K. Leslie \\
\hline & Changes in expression of some apoptotic markers in different types of human endometrium & $\begin{array}{l}\text { D. Driak, M. Dvorska, I. Svandova, B. Sehnal, K. Benkova, } \\
\text { Z. Spurkova and M. Halaska }\end{array}$ \\
\hline & $\begin{array}{c}7 \text { Methyl indole ethyl isothiocyanate causes ROS mediated apoptosis and cell cycle arrest in } \\
\text { endometrial cancer cells. }\end{array}$ & $\begin{array}{l}\text { K. Kristjansdottir, K. Kim, J. S. Choi, T. C. Horan, L. Brard, } \\
\text { R. G. Moore and R. K. Singh }\end{array}$ \\
\hline
\end{tabular}


Ricci S (2016) The role of poly(ADP-ribose) polymerase inhibitors in the treatment of endometrial cancer: a scoping review of the current literature

\begin{tabular}{|c|c|c|}
\hline \multirow[t]{14}{*}{$\begin{array}{l}\text { Not About Endometrial } \\
\text { Cancer }\end{array}$} & $\begin{array}{c}\text { A Study of Oral Rucaparib in Patients With a Solid Tumor (Phase I) or With gBRCA Mutation } \\
\text { Ovarian Cancer (Phase II) }\end{array}$ & CLINICAL TRIAL \\
\hline & $\begin{array}{l}\text { Effects of parathyroid hormone like hormone (PTHLH) antagonist, PTHLH(7-34), on } \\
\text { fetoplacental development and growth during midgestation in rats }\end{array}$ & C. S. Thota, L. C. Reed and C. Yallampalli \\
\hline & 'BRCAness' and Its Implications for Platinum Action in Gynecologic Cancer & F. Muggia and T. Safra \\
\hline & 'Triple negative' epithelial ovarian cancer and pathologic markers for prognosis & N. F. Liu, X. W. Wang and X. G. Sheng \\
\hline & $\begin{array}{l}\text { Tetrathiomolybdate sensitizes ovarian cancer cells to anticancer drugs doxorubicin, fenretinide, } \\
\text { 5-fluorouracil and mitomycin C }\end{array}$ & $\begin{array}{l}\text { K. K. Kim, T. S. Lange, R. K. Singh, L. Brard and R. G. } \\
\text { Moore }\end{array}$ \\
\hline & $\begin{array}{c}\text { Pre-eclampsia and maternal anaemia display reduced apoptosis and opposite invasive } \\
\text { phenotypes of extravilloustrophoblast }\end{array}$ & $\begin{array}{l}\text { M. Kadyrov, C. Schmitz, S. Black, P. Kaufmann and B. } \\
\text { Huppertz }\end{array}$ \\
\hline & PARP1 during embryo implantation and its upregulationby oestradiol in mice & $\begin{array}{l}\text { A. Joshi, S. Mahfooz, V. K. Maurya, V. Kumar, C. S. } \\
\text { Basanna, G. Kaur, K. Hanif and R. K. Jha }\end{array}$ \\
\hline & $\begin{array}{c}\text { Expression of BAG-1 and PARP-1 in Precursor Lesions and Invasive Cervical Cancer } \\
\text { Associated with Human Papillomavirus (HPV) }\end{array}$ & $\begin{array}{l}\text { M. K. Hassumi-Fukasawa, F. A. Miranda-Camargo, B. R. } \\
\text { Zanetti, D. F. Galano, A. Ribeiro-Silva and E. G. Soares }\end{array}$ \\
\hline & $\begin{array}{c}\text { The role of steroid hormones and decidual induction in the regulation of adenosine } \\
\text { diphosphoribosyltransferase activity in rat endometrium }\end{array}$ & A. M. Cummings \\
\hline & $\begin{array}{c}\text { Cyclooxygenase-2 regulates survival, migration, and invasion of human endometriotic cells } \\
\text { through multiple mechanisms }\end{array}$ & $\begin{array}{l}\text { S. K. Banu, J. Lee, V. O. Speights, Jr., A. Starzinski-Powitz } \\
\text { and J. A. Arosh }\end{array}$ \\
\hline & $\begin{array}{c}\text { OSU-A9, an indole-3-carbinol derivative, induces cytotoxicity in acute myeloid leukemia } \\
\text { through reactive oxygen species-mediated apoptosis }\end{array}$ & $\begin{array}{l}\text { L. Y. Bai, J. R. Weng, C. F. Chiu, C. Y. Wu, S. P. Yeh, A. M. } \\
\text { Sargeant, P. H. Lin and Y. M. Liao }\end{array}$ \\
\hline & Reduced Mitogenicity of Sera Following Weight Loss in Premenopausal Women & $\begin{array}{l}\text { M. Azrad, P. L. Chang, B. A. Gower, G. R. Hunter and T. } \\
\text { R. Nagy }\end{array}$ \\
\hline & $\begin{array}{l}\text { BRCA Mutation Frequency and Patterns of Treatment Response in BRCA Mutation-Positive } \\
\text { Women With Ovarian Cancer: A Report From the Australian Ovarian Cancer Study Group }\end{array}$ & $\begin{array}{c}\text { K. Alsop, S. Fereday, C. Meldrum, A. Defazio, C. } \\
\text { Emmanuel, J. George, A. Dobrovic, M. J. Birrer, P. M. } \\
\text { Webb, C. Stewart, M. Friedlander, S. Fox, D. Bowtell and } \\
\text { G. Mitchell }\end{array}$ \\
\hline & 'Triple negative' epithelial ovarian cancer and pathologic markers for prognosis. & N. F. Liu, X. W. Wang and X. G. Sheng \\
\hline \multirow{4}{*}{$\begin{array}{l}\text { Looks at PARP cleavage } \\
\text { products as markers } \\
\text { for apotosis, not PARP } \\
\text { inhibitors }\end{array}$} & $\begin{array}{c}\text { The Akt and ERK Activation by Platinum-based Chemotherapy in Ovarian Cancer is } \\
\text { Associated with Favorable Patient Outcome }\end{array}$ & $\begin{array}{l}\text { T. Ohta, M. Isobe, T. Takahashi, M. Saitoh-Sekiguchi, T. } \\
\text { Motoyama and H. Kurachi }\end{array}$ \\
\hline & $\begin{array}{c}\text { Sojucktang induces apoptosis via loss of mitochondrial membrane potential and caspase-3 } \\
\text { activation in KLE human endometrial cancer cell }\end{array}$ & $\begin{array}{l}\text { Y. S. Oh, H. Y. Kwon, S. J. Jeong, K. Y. Park, S. Y. Kim, H. } \\
\text { J. Lee, E. O. Lee, K. S. Ahn and S. H. Kim }\end{array}$ \\
\hline & GRP78 induced by estrogen plays a role in the chemosensitivity of endometrial cancer & $\begin{array}{l}\text { B. Luvsandagva, K. Nakamura, Y. Kitahara, H. Aoki, T. } \\
\text { Murata, S. Ikeda and T. Minegishi }\end{array}$ \\
\hline & $\begin{array}{l}\text { A novel role for placental leucineaminopeptidase (P-LAP) as a determinant of chemoresistance } \\
\text { in endometrial carcinoma cells }\end{array}$ & $\begin{array}{l}\text { C. Kondo, K. Shibata, M. Terauchi, H. Kajiyama, K. Ino, S. } \\
\text { Nomura, A. Nawa, S. Mizutani and F. Kikkawa }\end{array}$ \\
\hline \multirow{2}{*}{$\begin{array}{c}\text { Did Not Include } \\
\text { Discussion of PARP } \\
\text { Inhibitors for Endometrial } \\
\text { Cancer Treatment }\end{array}$} & Major clinical research advances in gynecologic cancer in 2012 & D. H. Suh, J. W. Kim, K. Kim, H. J. Kim and K. H. Lee \\
\hline & Major clinical research advances in gynecologic cancer in 2013 & D. H. Suh, J. W. Kim, S. Kang, H. J. Kim and K. H. Lee \\
\hline $\begin{array}{l}\text { Not Looking at PARP } \\
\text { Inhibitor Efficacy }\end{array}$ & $\begin{array}{l}\text { Veliparib, Paclitaxel, and Carboplatin in Treating Patients With Solid Tumors That Are } \\
\text { Metastatic or Cannot Be Removed by Surgery and Liver or Kidney Dysfunction }\end{array}$ & CLINICAL TRIAL \\
\hline
\end{tabular}

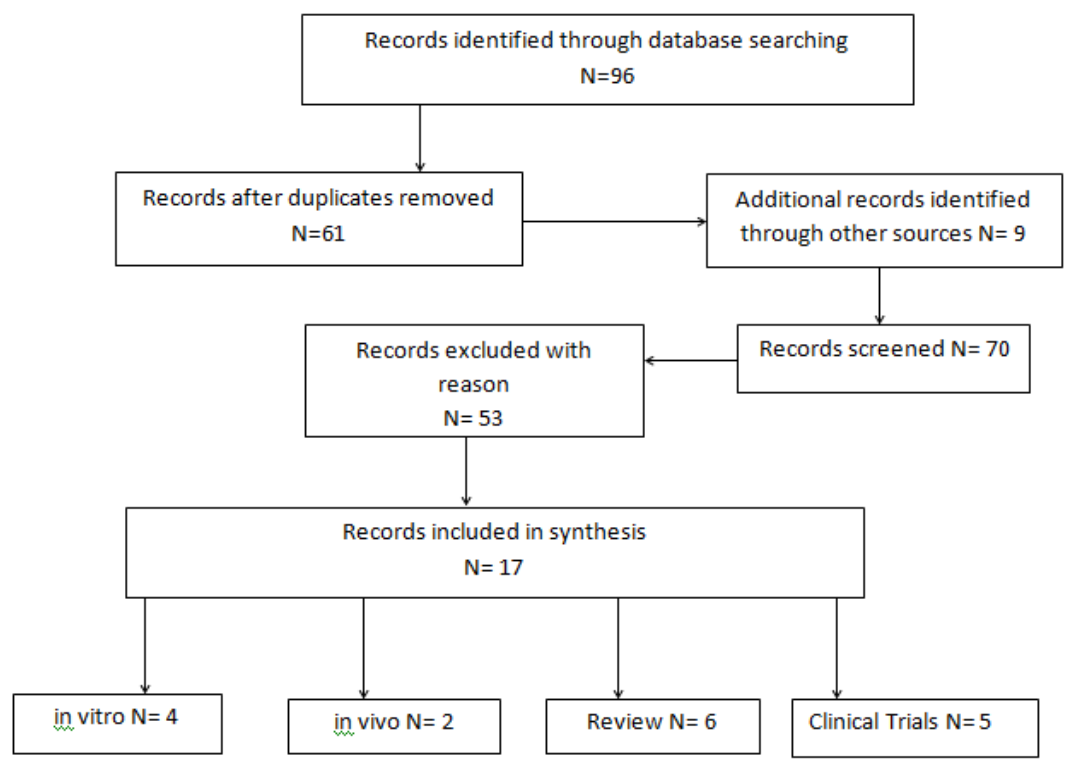

Figure 1. Flow diagram of included studies from scoping review. 
sensitive. The authors proposed that MRE11 expression may serve as a predictor of efficacy of PARP inhibitor treatment.

\section{In vivo studies}

Janzen et al., using PTEN-null endometrial cancer mouse model, evaluated the efficacy of the PARP inhibitor, olaparib, at low and high estrogen concentrations, done to recapitulate the hyperestrogenic state, secondary to obesity, found in most patients with endometrial cancer [36]. Tumors in oophorectomized mice kept in a low estrogen state had a six-fold decrease in tumor size when treated with olaparib, in contrast to no response to olaparib in mice exposed to high estrogen levels. In investigating the potential cellular mechanisms for this discrepancy they noted that the estrogen-deficient environment was associated with increased levels of olaparib at the tumor bed and decreased levels of Rad51, a component of the homologous recombination pathway, and a potential indicator of PARP-inhibitor sensitivity. These findings suggest that PARP inhibition, in combination with hormonal therapy, may increase anti-tumor efficacy.

Forster et al. detailed a case of a post-menopausal BRCA-negative woman with recurrent, metastatic, including brain metastases, PTENnegative endometrial cancer [35]. The patient was treated with olaparib and experienced a significant symptomatic and radiographic response, including an initial resolution of neurologic symptoms and reduction in size of cerebral lesions. She continued to have a mixed-tumor response and was maintained on olaparib for 8 months, in addition to receiving gamma-knife and cyber-knife radiosurgery for cerebral and extracranial lesions. The patient remained alive for 10 months after completing olaparib treatment.

\section{Reviews}

Several review articles $[7,37,38]$ noted that in addition to the promising role PARP inhibitors may play in the treatment of BRCA mutation-associated breast and ovarian cancer, these drugs may have a wider application in the treatment of cancers with defective DNA damage repair pathways other than BRCA mutations.

Other reviews $[3,39,40]$ commented on the promising results of recent studies and those underway at the time of publication, but noted that further clinical evaluation of the potential utility of PARP inhibitors in the treatment of endometrial cancer is needed.

\section{Clinical trials}

Currently, there are clinical trials evaluating the use of PARP inhibitors in endometrial cancer. There is an ongoing clinical trial evaluating the combination of olaparib and carboplatin in treating women with recurrent endometrial cancer (NCT01237067). A phase I trial comparing the highest tolerable doses and combinations of the drugs olaparib, AZD2014, and AZD5363 that can be given to patients with recurrent endometrial (NCT02208375) is recruiting participants. A clinical trial of the PARP inhibitor BMN673 for advanced, inoperable endometrial cancer (PANDA) will soon be recruiting patients (NCT02127151). A Phase I study of the PARP inhibitor MK-4827 in participants with persistent or recurrent endometrial carcinoma was recently completed (NCT00749502).

\section{Discussion}

The objective of this review was to review the available literature on the role of PARP inhibitors in the treatment of endometrial cancer. In total, 69 articles were evaluated and 17 were chosen for inclusion in the review.
Studies have shown conflicting evidence regarding the susceptibility of PTEN null endometrial cancer cells to PARP inhibitors. Data from Dedes et al. suggest that PTEN null endometrial cancer cells are more susceptible to PARP inhibition than cells with wild type PTEN. In contrast, results from Miyasaka suggest that lack of PTEN expression does not increase sensitivity to the PARP inhibitor olaparib. The discordance of these results may stem from the difference in number and type of endometrial cell lines tested. Dedes et al. included 2 PTEN wild type cell lines, whereas Miyasaka et al. included 4 PTEN wild type cell lines, including three different PTEN mutant cell lines (HEC-6, HEC-116, and HEC-108).

The sensitivity of the tumor to PARP inhibition may be altered by the hormonal milieu of the tumor [36]. In an in vivo study by Janzen $e t$ al., in a high estrogen state, peak olaparib concentrations, comparable to serum concentrations in humans treated with the common dose of 400 mg olaparib twice daily, were achieved at 2 hours. In contrast, in a low estrogen state, the peak concentration was achieved earlier, after only 30 minutes, and reached a concentration twenty times higher than in the high estrogen state. Additionally, CYP3A4, the enzyme responsible for the majority of olaparib metabolism in humans, is reported to be regulated by estrogen concentrations. Levels of CYP3A4, mouse homolog, had transcripts in higher concentration in the estrogen treated versus estrogen depleted mice. These findings that tumors in a high estrogen environment may be more resistant to PARP inhibition than those in a low estrogen environment may ultimately have clinical implications, as the level of estrogen in endometrial cancer patients may often be elevated secondary to obesity [41] and can be manipulated with drugs such as aromatase inhibitors or oophorectomy.

In a case study reported by Forster and colleagues [35], a patient with recurrent, metastatic PTEN null endometrial cancer derived benefit, both subjective and objective, from treatment with olaparib. In addition to reporting decreased symptoms related to her metastases, imaging studies evidenced objective improvement in tumor burden.

We have reported on our thorough review of literature regarding the PARP inhibition in endometrial cancer. Available evidence suggests that PARP inhibitors hold promise in the treatment of endometrial cancer. Human studies are needed to definitively elucidate the role of these drugs in treating endometrial cancer. Patient selection will be of paramount importance and would benefit from further investigation into the role of PTEN and MRE11 mutations as potential biomarkers for sensitivity to PARP inhibition. Patient hormonal status (i.e., estrogen level) and possible manipulation must be considered when prescribing PARP inhibitor treatment. The ideal balance of efficacy with toxicity of PARP inhibitors as monotherapy versus combination with cytotoxic chemotherapy will warrant further investigation, as well as optimal duration of treatment, long term side effects of treatment, and mechanisms of development of resistance remain to be determined and have important implications in the use of PARP inhibitors for recurrent or advanced endometrial cancer.

\section{Acknowledgements}

The authors would like to recognize Kathy Shrawder for her editorial and clerical expertise in the preparation of this manuscript.

\section{References}

1. Siegel RL, Miller KD, Jemal A (2015) Cancer statistics, 2015. CA Cancer J Clin 65: 5-29. [Crossref]

2. Curtin NJ, Szabo C (2013) Therapeutic applications of PARP inhibitors: anticancer therapy and beyond. Mol Aspects Med 34: 1217-1256. [Crossref] 
3. Dellinger TH, Monk BJ (2009) Systemic therapy for recurrent endometrial cancer: a review of North American trials. Expert Rev Anticancer Ther 9: 905-916. [Crossref]

4. Fleming GF (2007) Systemic chemotherapy for uterine carcinoma: metastatic and adjuvant. J Clin Oncol 25: 2983-2990. [Crossref]

5. Fleming GF, Brunetto VL, Cella D, Look KY, Reid GC, et al. (2004) Phase III trial of doxorubicin plus cisplatin with or without paclitaxel plus filgrastim in advanced endometrial carcinoma: a Gynecologic Oncology Group Study. J Clin Oncol 22: 21592166. [Crossref]

6. Fleming GF, Filiaci VL, Bentley RC, Herzog T, Sorosky J, et al. (2004) Phase III randomized trial of doxorubicin + cisplatin versus doxorubicin +24 -h paclitaxel + filgrastim in endometrial carcinoma: a Gynecologic Oncology Group study. Ann Oncol 15: 1173-1178. [Crossref]

7. Banerjee S, Kaye S (2011) PARP inhibitors in BRCA gene-mutated ovarian cancer and beyond. Curr Oncol Rep 13: 442-449. [Crossref]

8. Reinbolt RE, Hays JL (2013) The Role of PARP Inhibitors in the Treatment of Gynecologic Malignancies. Front Oncol 3: 237. [Crossref]

9. Haince JF, Kozlov S, Dawson VL, Dawson TM, Hendzel MJ, et al. (2007) Ataxia telangiectasia mutated (ATM) signaling network is modulated by a novel poly(ADPribose)-dependent pathway in the early response to DNA-damaging agents. $J$ Biol Chem 282: 16441-16453. [Crossref]

10. Bryant HE, Petermann E, Schultz N, Jemth AS, Loseva O, et al. (2009) PARP is activated at stalled forks to mediate Mre11-dependent replication restart and recombination. EMBO J 28: 2601-2615. [Crossref]

11. Rouleau M, Patel A, Hendzel MJ, Kaufmann SH, Poirier GG (2010) PARP inhibition: PARP1 and beyond. Nat Rev Cancer 10: 293-301. [Crossref]

12. Murai J, Huang SY, Das BB, Renaud A, Zhang Y, et al. (2012) Trapping of PARP1 and PARP2 by Clinical PARP Inhibitors. Cancer Res 72: 5588-5599. [Crossref]

13. Boulton S, Kyle S, Durkacz BW (1999) Interactive effects of inhibitors of poly(ADPribose) polymerase and DNA-dependent protein kinase on cellular responses to DNA damage. Carcinogenesis 20: 199-203. [Crossref]

14. Dedes KJ, Wetterskog D, Mendes-Pereira AM, Natrajan R, Lambros MB, et al. (2010) PTEN deficiency in endometrioid endometrial adenocarcinomas predicts sensitivity to PARP inhibitors. Sci Transl Med 2: 53ra75. [Crossref]

15. McCabe N, Turner NC, Lord CJ, Kluzek K, Bialkowska A, et al. (2006) Deficiency in the repair of DNA damage by homologous recombination and sensitivity to poly(ADPribose) polymerase inhibition. Cancer Res 66: 8109-8115. [Crossref]

16. Audeh MW, Carmichael J, Penson RT, Friedlander M, Powell B, et al. (2010) Ora poly(ADP-ribose) polymerase inhibitor olaparib in patients with BRCA1 or BRCA2 mutations and recurrent ovarian cancer: a proof-of-concept trial. Lancet 376: 245-251. [Crossref]

17. Farmer H, McCabe N, Lord CJ, Tutt AN, Johnson DA, et al. (2005) Targeting the DNA repair defect in BRCA mutant cells as a therapeutic strategy. Nature 434: 917-921. [Crossref]

18. Kaye SB, Lubinski J, Matulonis U, Ang JE, Gourley C, et al. (2012) Phase II, openlabel, randomized, multicenter study comparing the efficacy and safety of olaparib, a poly (ADP-ribose) polymerase inhibitor, and pegylated liposomal doxorubicin in patients with BRCA1 or BRCA2 mutations and recurrent ovarian cancer. J Clin Oncol 30: 372-379. [Crossref]

19. Tutt A, Robson M, Garber JE, Domchek SM, Audeh MW, et al. (2010) Oral poly(ADPribose) polymerase inhibitor olaparib in patients with BRCA1 or BRCA2 mutations and advanced breast cancer: a proof-of-concept trial. Lancet 376: 235-244. [Crossref]

20. Sandhu SK, Schelman WR, Wilding G, Moreno V, Baird RD, et al. (2013) The poly(ADP-ribose) polymerase inhibitor niraparib (MK4827) in BRCA mutation carriers and patients with sporadic cancer: a phase 1 dose-escalation trial. Lancet Oncol 14: 882-892. [Crossref]

21. Drew Y, Mulligan EA, Vong WT, Thomas HD, Kahn S, et al. (2011) Therapeutic potential of poly(ADP-ribose) polymerase inhibitor AG014699 in human cancers with mutated or methylated BRCA1 or BRCA2. J Natl Cancer Inst 103: 334-346. [Crossref]

22. Turner N, Tutt A, Ashworth A (2004) Hallmarks of 'BRCAness' in sporadic cancers Nat Rev Cancer 4: 814-819. [Crossref]

23. Shen WH, Balajee AS, Wang J, Wu H, Eng C, et al. (2007) Essential role for nuclear PTEN in maintaining chromosomal integrity. Cell 128: 157-170. [Crossref]

24. Hecht JL, Mutter GL (2006) Molecular and pathologic aspects of endometrial carcinogenesis. J Clin Oncol 24: 4783-4791. [Crossref]

25. Ioffe YJ, Chiappinelli KB, Mutch DG, Zighelboim I, Goodfellow PJ (2012) Phosphatase and tensin homolog (PTEN) pseudogene expression in endometrial cancer: a conserved regulatory mechanism important in tumorigenesis? Gynecol Oncol 124: 340-346. [Crossref]

26. Mutter GL, Lin MC, Fitzgerald JT, Kum JB, Baak JP, et al. (2000) Altered PTEN expression as a diagnostic marker for the earliest endometrial precancers. J Natl Cancer Inst 92: 924-930. [Crossref]

27. Temkin SM, Fleming G (2009) Current treatment of metastatic endometrial cancer Cancer Control 16: 38-45. [Crossref]

28. Lamarche BJ, Orazio NI, Weitzman MD (2010) The MRN complex in double-strand break repair and telomere maintenance. FEBS Lett 584: 3682-3695. [Crossref]

29. Stracker TH, Petrini JH (2011) The MRE11 complex: starting from the ends. Nat Rev Mol Cell Biol 12: 90-103. [Crossref]

30. Giannini G, Rinaldi C, Ristori E, Ambrosini MI, Cerignoli F, et al. (2004) Mutations of an intronic repeat induce impaired MRE11 expression in primary human cancer with microsatellite instability. Oncogene 23: 2640-2647. [Crossref]

31. Price JC, Pollock LM, Rudd ML, Fogoros SK, Mohamed H, et al. (2014) Sequencing of candidate chromosome instability genes in endometrial cancers reveals somatic mutations in ESCO, CHTF18, and MRE11A. PLoS One 8: e63313. [Crossref]

32. Miyasaka A, Oda K, Ikeda Y, Wada-Hiraike O, Kashiyama T, et al. (2014) Anti-tumor activity of olaparib, a poly (ADP-ribose) polymerase (PARP) inhibitor, in cultured endometrial carcinoma cells. BMC Cancer 14: 179. [Crossref]

33. Koppensteiner R, Samartzis EP, Noske A, von Teichman A, Dedes I, et al. (2014) Effect of MRE11 loss on PARP-inhibitor sensitivity in endometrial cancer in vitro. PLoS One 9: e100041. [Crossref]

34. Dedes KJ WD, Mendes-Pereira AM, Vatcheva R, Natrajan R, Lambros Bet al. (2010) Preclinical evaluation of PARP inhibition as a treatment for endometrioid endometrial carcinomas. J Clin Oncol 28: suppl; abstr 5065.

35. Forster MD, Dedes KJ, Sandhu S, Frentzas S, Kristeleit R, et al. (2011) Treatment with olaparib in a patient with PTEN-deficient endometrioid endometrial cancer. Nat Rev Clin Oncol 8: 302-306. [Crossref]

36. Janzen DM, Paik DY, Rosales MA, Yep B, Cheng D, et al. (2013) Low levels of circulating estrogen sensitize PTEN-null endometrial tumors to PARP inhibition in vivo. Mol Cancer Ther 12: 2917-2928. [Crossref]

37. Lee JM, Ledermann JA, Kohn EC (2014) PARP Inhibitors for BRCA1/2 mutationassociated and BRCA-like malignancies. Ann Oncol 25: 32-40. [Crossref]

38. O'Sullivan CC, Moon DH2, Kohn EC, Lee JM1 (2014) Beyond Breast and Ovarian Cancers: PARP Inhibitors for BRCA Mutation-Associated and BRCA-Like Solid Tumors. Front Oncol 4: 42. [Crossref]

39. Tsoref D, Oza AM (2011) Recent advances in systemic therapy for advanced endometrial cancer. Curr Opin Oncol 23: 494-500. [Crossref]

40. Dedes KJ, Wetterskog D, Ashworth A, Kaye SB, Reis-Filho JS (2011) Emerging therapeutic targets in endometrial cancer. Nat Rev Clin Oncol 8: 261-271. [Crossref]

41. Cramer DW (2012) The epidemiology of endometrial and ovarian cancer. Hematol Oncol Clin North Am 26: 1-12. [Crossref]

Copyright: (C2016 Ricci S. This is an open-access article distributed under the terms of the Creative Commons Attribution License, which permits unrestricted use, distribution, and reproduction in any medium, provided the original author and source are credited. 